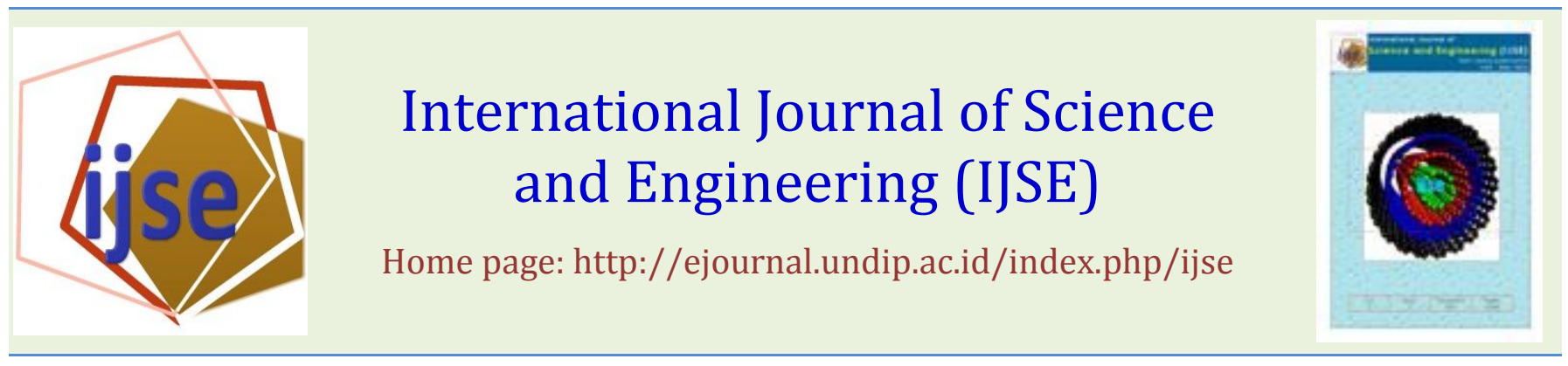

\title{
Nitrogen Retention and Productive Performance of Crossbred Native Chicken Due to Feeding Effect of Kayambang (Salvinia molesta)
}

\author{
B. Ma'rifah ${ }^{1}$, U. Atmomarsono², N. Suthama ${ }^{3}$ \\ Faculty of Animal Science and Agriculture, Diponegoro University \\ Tembalang Campus, Semarang 50275 - Indonesia \\ ${ }^{1}$ binti_tehate@yahoo.com; ${ }^{2}$ umiyati.atmomarsono@gmail.com; ${ }^{3}$ nsuthama@yahoo.com
}

\begin{abstract}
The present research was aimed to clarify the effect of feeding Salvinia molesta in crossbred native chicken on productive performance based on the ability of protein utilitation. The reseach was arranged in a completely randomized design with 4 treatments and 5 replications ( 5 birds each). The animals used in the present study were 100 birds of crossbred native chicken. The treatments given were as follows: T0 (diet without Salvinia molesta), T1 (diet with 6\% Salvinia molesta), T2 (diet with $12 \%$ Salvinia molesta), T3 (diet with 18\% Salvinia molesta). Parameter observed namely feed consumption, nitrogen retention, muscle protein mass, and body weight gain. The data were analysed using anova, when the effect of the treatments was significant, then duncan's multiple range test was applied. The results showed that the treatment of feeding Salvinia molesta indicated a sinificant effect ( $\mathrm{p}<0.05)$ on nitrogen retention and productive performance. Feed consumption, nitrogen retention, muscle protein mass, and the body weight gain of $\mathrm{T} 1, \mathrm{~T} 2$, and $\mathrm{T} 3$ were significantly higher $(\mathrm{p}<0.05)$ than those of control $(\mathrm{t} 0)$, while among treatments $\mathrm{T} 1$, $\mathrm{T} 2$, and $\mathrm{T} 3 \mathrm{were}$ not different. Feeding Salvinia molesta up to the level of $18 \%$ can improve nitrogen retention and productive perfomance of crossbred native chicken.
\end{abstract}

[keywords - $\quad$ kayambang (Salvinia molesta); crossbred native chicken; muscle protein mass; body weight gain; productive performance]

Submission: March 17, 2013

Corrected : June 22, 2013

Accepted: July 3, 2013

Doi: $10.12777 /$ ijse.5.1.19-24

[How to cite this article: Ma'rifah, U. Atmomarsono, N. Suthama. (2013). Nitrogen Retention and Productive Performance of Crossbred Native Chicken Due to Feeding Effect of Kayambang (Salvinia molesta), 5(1)2013.19-24. Doi: 10.12777/ijse.5.1.19-24 ]

\section{INTRODUCTION}

Native chickens are local bird that don't have specific characteristics, but it can be found easily in all over Indonesia because many farmers raised this type of chicken. Indonesian peoples prefer to consume products of native chicken rather than those of broiler because of its egg and meat's taste are better. In addition to the better taste, egg and meat of a native chicken are believed to contain higher nutritional values which bringing about the selling price is relatively more expensive compared to that of broiler chicken products. However, productivity of native chicken is low due to the raising model applied is very simple, and also genetically low feed utilization efficiency. The low genetic ability of native chicken brought about many efforts have been conducted, one is that by cross-mating between native chicken and modern breed in order to get specific genetic trait that is not far different from the original ancestor (native chicken) but its productivity having higher economic value. Crossbred native chicken is the offspring of cross breeding between native chicken (male) and Isa Brown of egg-laying hen. Crossbred native chickens are able to produce meat with the characteristics, such as flavor and taste, similar to those of native chicken, but the growth rate is faster and slaughtering age is sorter for market. According to Muryanto (2005), crossbred native chicken can reach body weight for consumption $(0.85 \mathrm{~kg})$ at the age of 60 days with intensive rearing management, while original native chicken can reach only $0.5 \mathrm{~kg}$ at the same age.

Nutritional supplies, especially protein, for poultry, including crossbred native chickens, should be adequate and meet requirement level. The adequacy of protein requirement is always connected with dietary metabolizable energy, so called the balance ratio between energy and protein. Generally, protein sources for poultry diet is fulfilled from fish meal. It is well known that fish meal is functioning as one ideal protein source with high amino acids content and balance. However, considering dietary inclusion of fish meal causes less efficiency of productive cost of crossbred native chicken 
farming, it is reliable to find an alternative local feedstuff with high enough protein content to partly substituted fish meal. One local feedstuff as an alternative ingredient can be included into the poultry diet with lower price but high protein content is known as kayambang or it's scientific name called Salvinia molesta.

Salvinia molesta is a type of free floating aquatic fern that mostly grows in marshes, rivers, and also rice field area. Agronomically, Salvinia molesta grows fast, within 14 days its growth can reach as twice as the initial amount, therefore, within a year can produce as much as 45.6 up to 109.5 ton/hectare in fresh (McFarland et al., 2004). Salvinia molesta is possible to be used as poultry diet component because of its high protein content, reaching 30\%. Salvinia molesta, an aquatic plant, is belong to the family of duckweed that is very potential for poultry diet (Bell, 1998). The content of protein in duckweed reaches $30-35 \%$, duckweed is also rich of essential amino acids such as lysine and methionine, important minerals, and xanthophyll pigment which is very good for the poultry diet. According to Porath et al. (1979) cited by Akter et al. (2011), duckweed contains balanced amino acid especially for lysine (6.9 g/100g protein), methionine $(1.59 \mathrm{~g} / 100 \mathrm{~g}$ protein), potential mineral and pigment source for poultry especially beta-carotene and xanthophyll content. The amount of beta-carotene in Salvinia molesta, as one of the duckweed family, is 10 times higher than that in other plants, while the amount of xanthophyll content is 1,000 ppm. Based on Halolo and Silalahi (1997) cited by Sumiati and Sumirat (2003), Salvinia molesta in the form of dried meal can be used in broiler chicken diet up to the level of $12 \%$.

In relation to the growth acceleration, Salvinia molesta is greatly possible to be used as a component of crossbred native chicken diet due to its high protein content. Animal needs energy and substrate supplies for optimal growth of sel or tissue that is achieved by diet containing adequate protein. According to Widyaratne and Drew (2011), feed intake is influened by the diet quality, where is a balanced of diet protein influnced by amino acid concentration especially lysine . High quality diet for poultry usually contains complete and balanced amino acid to support growth. In addition, Suthama et al. (1998) reported that there was a close relationship between improved growth of native chicken and feed intake which is influenced by the availability of nutrient, especially protein. When diet contains more protein with better balanced and adequate amount of amino acid, it can increase body weight and efficiency of dietary protein utilization.

According to the background described previously, Salvinia molesta was used as a dietary component and its protein contributing effect for crossbred native chickens was evaluated. The response of crossbred chickens against the feeding effect of Salvinia molesta, based on protein utilization and growth, was discussed in the present study.

\section{MATERIAL AND METHOD}

The present study entitled " Nitrogen Retention and Productive Performance of Crossbred Native Chicken Due to Feeding Effect of Kayambang (Salvinia molesta)" was conducted from August 2012 to December 2012 at the Laboratory of Poultry Production, Faculty of Animal Science and Agriculture, Diponegoro University, Semarang. Samples of diet ingredient, meat, and excreta were analyzed at the Laboratory of Nutrition and Feed Science, Faculty of Animal Science and Agriculture, Diponegoro University.

A hundred birds of crossbred native chicken (crossing between male native chicken and modern laying hen) of 3week-old with an average initial body weight of $218.76 \pm$ $0.54 \mathrm{~g}$ was used as experimental animals. The birds were placed at the battery cages equipped with feeder box and watering bowl. Corn, soybean meal, coconut oil, rice bran, fish meal, $\mathrm{CaCO}_{3}$, premix, methionine, lysine, and Salvinia molesta were the components for experimental diet formulation. Salvinia molesta was obtained from Banyubiru river irrigation area (Central Java). Salvinia molesta was given in the form of dried meal. Diet was formulated containing approximately isoprotein (20 and 19\% for starter and finisher periods, respectively) and isocaloric $(2,900$ $\mathrm{kcal} / \mathrm{kg}$ for both starter and finisher periods) as shown in Table 1 and Table 2.

\begin{tabular}{|c|c|c|c|c|}
\hline Feed Ingredients & $\begin{array}{l}\text { T0 } \\
(0 \%)\end{array}$ & $\begin{array}{l}\text { T1 } \\
(6 \%)\end{array}$ & $\begin{array}{l}\mathrm{T} 2 \\
(12 \%)\end{array}$ & $\begin{array}{l}\text { T3 } \\
(18 \%)\end{array}$ \\
\hline Corn & 52,10 & 52,30 & 51,00 & 51,80 \\
\hline Soybean Meal & 21,30 & 17,00 & 14,00 & 10,80 \\
\hline Oil & 1,20 & 1,20 & 1,30 & 1,30 \\
\hline Bran & 16,80 & 15,90 & 15,10 & 11,80 \\
\hline Fish Meal & 5,00 & 5,00 & 5,00 & 5,00 \\
\hline $\mathrm{CaCO}_{3}$ & 0,80 & 0,70 & 0,40 & 0,40 \\
\hline Premix & 0,80 & 0,70 & 0,40 & 0,30 \\
\hline Methionine & 1,00 & 0,60 & 0,40 & 0,30 \\
\hline Lysine & 1,00 & 0,60 & 0,40 & 0,30 \\
\hline Salvinia molesta & 0,00 & 6,00 & 12,00 & 18,00 \\
\hline Total & 100,00 & 100,00 & 100,00 & 100,00 \\
\hline \multicolumn{5}{|l|}{ Nutrient } \\
\hline \multicolumn{5}{|l|}{ Composition: } \\
\hline $\mathrm{EM}(\mathrm{kcal} / \mathrm{kg})^{*}$ & $2.900,71$ & $2.900,84$ & $2.900,31$ & $2.900,80$ \\
\hline $\mathrm{PK}(\%)^{* *}$ & 20,32 & 20,04 & 20,27 & 20,33 \\
\hline $\operatorname{LK}(\%)^{* *}$ & 5,04 & 4,94 & 4,91 & 4,68 \\
\hline $\mathrm{SK}(\%)^{* *}$ & 6,22 & 8,36 & 10,57 & 12,10 \\
\hline Methionine $(\%)^{* * *}$ & 1,26 & 0,88 & 0,68 & 0,58 \\
\hline Lysine $(\%)^{* * * *}$ & 1,55 & 1,15 & 0,95 & 0,82 \\
\hline Calsium $(\%)^{* * *}$ & 1,24 & 1,20 & 0,95 & 1,01 \\
\hline Phospor $(\%)^{* * * *}$ & 0,72 & 0,71 & 0,71 & 0,67 \\
\hline \multicolumn{5}{|c|}{ ted by Sibl } \\
\hline $\mathrm{ME}=40,81$ & $\mathrm{CP}+2,25 \mathrm{C}$ & $+\mathrm{BETN})$ & K ) $\quad \mathrm{K}$ & 4,9 \\
\hline $\begin{array}{l}\text { Proximate Ana } \\
\text { Faculty of An }\end{array}$ & $\begin{array}{l}\text { in Nutritio } \\
\text { Science an }\end{array}$ & $\begin{array}{l}\text { and Feed Sc } \\
\text { Agriculture }\end{array}$ & $\begin{array}{l}\text { ence Labor } \\
\text { Diponegoro }\end{array}$ & $\begin{array}{l}\text { orium, } \\
\text { Jniversity }\end{array}$ \\
\hline
\end{tabular}

The study was conducted using completely random design with 4 treatments and 5 replications ( 5 birds each), thus there were 20 unit experiments. Dietary treatments were as follows; T0 (diet without Salvinia molesta), T1 (diet with 6\% Salvinia molesta), T2 (diet with 12\% Salvinia molesta), T3 (diet with $18 \%$ Salvinia molesta). Experimental diets started to be offered from 3-week-old and completed when the chickens were 10-week-old. Diet and drinking water were offered ad libitium. The parameters observed were feed consumption, nitrogen retention, muscle protein mass, and body weight gain. Data were subjected to analysis of variance, and it was continued to Duncan test at a probably level of 5\% when the treatment indicated significant effect. 
Table 2. Feed Ingredients and Nutrient Composition for Finisher Period.

\begin{tabular}{|c|c|c|c|c|}
\hline Feed Ingredients & $\begin{array}{l}\text { T0 } \\
(0 \%)\end{array}$ & $\begin{array}{l}\mathrm{T} 1 \\
(6 \%)\end{array}$ & $\begin{array}{l}\mathrm{T} 2 \\
(12 \%)\end{array}$ & $\begin{array}{l}\text { T3 } \\
(18 \%)\end{array}$ \\
\hline Corn & 54,00 & 52,90 & 52,60 & 52,50 \\
\hline Soybean Meal & 19,30 & 16,50 & 12,70 & 9,40 \\
\hline Oil & 1,20 & 1,10 & 1,20 & 1,20 \\
\hline Bran & 17,70 & 17,60 & 16,40 & 14,60 \\
\hline Fish Meal & 4,00 & 3,50 & 3,50 & 3,50 \\
\hline $\mathrm{CaCO}_{3}$ & 1,00 & 0,70 & 0,40 & 0,20 \\
\hline Premix & 1,00 & 0,50 & 0,40 & 0,20 \\
\hline Methionine & 0,90 & 0,60 & 0,40 & 0,20 \\
\hline Lysine & 0,90 & 0,60 & 0,40 & 0,20 \\
\hline Salvinia molesta & 0,00 & 6,00 & 12,00 & 18,00 \\
\hline Total & 100,00 & 100,00 & 100,00 & 100,00 \\
\hline \multicolumn{5}{|l|}{ Nutrient } \\
\hline \multicolumn{5}{|l|}{ Composition : } \\
\hline $\mathrm{EM}(\mathrm{kcal} / \mathrm{kg})^{*}$ & $2.902,62$ & $2.901,51$ & $2.901,97$ & $2.902,10$ \\
\hline $\mathrm{PK}(\%)^{* *}$ & 19,02 & 19,14 & 19,03 & 19,12 \\
\hline $\operatorname{LK}(\%)^{* * *}$ & 5,09 & 4,91 & 4,87 & 4,71 \\
\hline SK $(\%)^{* *}$ & 6,31 & 8,68 & 10,75 & 12,68 \\
\hline Methionine $(\%)^{\text {*** }}$ & 1,14 & 0,85 & 0,65 & 0,46 \\
\hline Lysine $(\%)^{* * *}$ & 1,42 & 1,12 & 0,91 & 0,69 \\
\hline Calsium $(\%)^{* * *}$ & 1,36 & 1,08 & 0,84 & 0,69 \\
\hline Phospor $(\%)^{* * *}$ & 0,68 & 0,68 & 0,67 & 0,66 \\
\hline
\end{tabular}

* $\quad$ ME was calculated with Balton formula that sited by Sibbald (1989) $\mathrm{ME}=40,81(0,87(\mathrm{CP}+2,25 \mathrm{CF}+\mathrm{BETN})+\mathrm{K}) \quad \mathrm{K}=4,9$

** Proximate Analised in Nutrition and Feed Science Laboratorium, Faculty of Animal Science and Agriculture, Diponegoro University *** Table of Feedstuff Composition by Amrullah (2004)

\section{RESULTS AND DISCUSSION}

Feed consumption, nitrogen retention, muscle protein mass, and body weight gain of crossbred native chickens were significantly $(\mathrm{P}<0.05)$ affected by feeding Salvinia (Table 3$)$. Birds given control diet without Salvinia (T0) showed the lowest feed consumption $(\mathrm{P}<0.05)$ compared to other treatments with Salvinia (T1,T2,T3), but feed consumption among the three treatments $(\mathrm{T} 1, \mathrm{~T} 2, \mathrm{~T} 3)$ were not different (Figure 1). The higher feed consumption of treatments T1, T2, and T3 compared to control could be caused by the difference of diet components. Since the treatments of T1, T2, and T3 composed of Salvinia it is obvious that its protein or amino acid contents contributed to the better amino acid balance due to the complementary effect with animal protein source used in the diet. Salvinia, an aquatic plant, is belong to the family of duckweed that is very potential for poultry diet (Bell, 1998). According to Porath et al. (1979) cited by Akter et al. (2011), duckweed contains balanced amino acid especially for lysine (6.9 $\mathrm{g} / 100 \mathrm{~g}$ protein), methionine (1.59 $\mathrm{g} / 100 \mathrm{~g}$ protein), potential mineral and pigment source for poultry especially beta-carotene and xanthophyll content. The amount of betacarotene in Salvinia, as one of the duckweed family, is 10 times higher than that in other plants, while the amount of xanthophyll content is $1,000 \mathrm{ppm}$.

Table 3. Feed consumption, nitrogen retention, muscle protein mass, and body weight gain of crossbred native chicken given Salvinia molesta

\begin{tabular}{|c|c|c|c|c|}
\hline \multirow{2}{*}{ Parameters } & \multicolumn{4}{|c|}{ Treatment } \\
\hline & T0 & $\mathrm{T} 1$ & $\mathrm{~T} 2$ & T3 \\
\hline 1. Feed Consumption (g/bird/day) & $38,08^{b}$ & $49,95^{\mathrm{a}}$ & $51,63^{\mathrm{a}}$ & $54,30^{\text {a }}$ \\
\hline 2. Nitrogen Retention (g) & $1,11^{\mathrm{b}}$ & $2,06^{\mathrm{a}}$ & $1,92^{\mathrm{a}}$ & 1,90 \\
\hline 3. Muscle Protein Mass (g) & $51,40^{\mathrm{b}}$ & $126,32^{a}$ & $140,37^{a}$ & 134,98 \\
\hline 4. Body Weight Gain (g/bird) & $308,56^{b}$ & $657,12^{\mathrm{a}}$ & $721,20^{\mathrm{a}}$ & 733.12 \\
\hline
\end{tabular}

Value bearing different superskrip in the same raw indicated significantly different $(\mathrm{P}<0.05)$

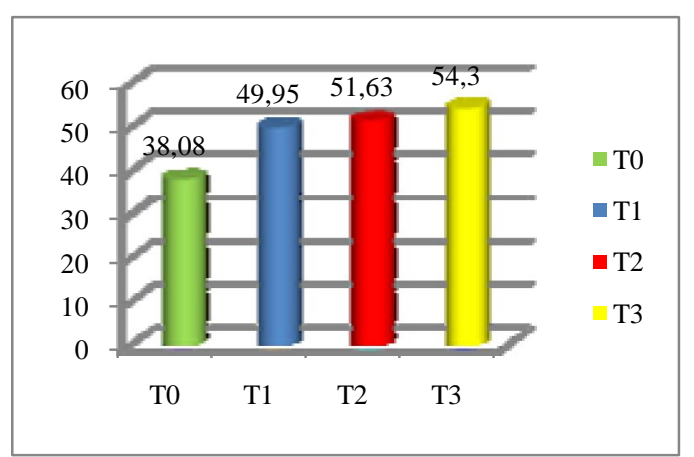

Fig. 1 Feed Consumption in Crossbred Native Chicken given Salvinia

According to Widyaratne and Drew (2011), feed consumption is influened by the diet quality, where is a balanced of diet protein influnced by amino acid concentration especially lysine. High quality diet contains complete and balanced amino acid is important to be effectively used by poultry to support its growth. In addition, Suthama et al. (1998) reported that feed consumption is influenced by the availability of nutrient, especially protein attributed by complete essential amino acids. When diet contains more protein with better balanced of amino acid, it can increase feed consumption and efficiency of dietary protein utilitation.
The increased feed consumption resulted in the present research was in lines with the increase in amino acid content in diet, especially lysine. Thi My Tu (2012) reported that feed consumption in duck increased from $92.1 \mathrm{~g}$ to $104 \mathrm{~g}$ by feeding effect of duckweed contained $30 \%$ protein. The present result was also similar with the finding of Donsbough (2008) that the increase in feed consumption of broiler from $37,49 \mathrm{~g}$ to $40,66 \mathrm{~g}$ was consistent with the increase in dietary amino acid, especially lysine.

The pattern of nitrogen retention was similar to that of feed consumption which dietary Salvinia treatments (T1,T2,T3 resulted significantly higher nitrogen retention $(\mathrm{P}<0.05)$ when compared to control (T0) as shown in Figure 2. Nitrogen retention should be have a close relationship with the efficiency of protein utilitation. Dietary protein have a positive correlation with protein consumption, while nitrogen retention influenced by protein consumption. This phenomenon was supported by the data of protein consumption, namely, treatment T1, T2 and T3 was 11,22 ; 11,$21 ; 11,01 \mathrm{~g} / \mathrm{bird} /$ day, respectively, and these valus were higher than that of control $(8,69 \mathrm{~g} / \mathrm{bird} / \mathrm{day})$. Suthama et al. (2010) obtained that there is a close interrelationship between the increasing protein diet and protease enzyme activity, where the higher enzyme activity, the better nitrogen retention resulted due to the biochemical process of dietary protein hydrolysis. Nitrogen retention is also influenced by dietary 
energy supply. It was still supported by the finding of Suthama (2010), when dietary energy is not available enough, althought protein as a substrate is available, it can inhibit the utilization of nitrogen or nitrogen retention process.

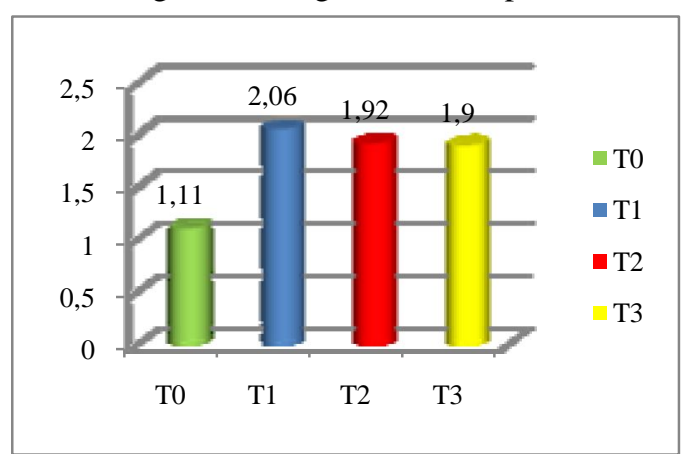

Fig. 2 Nitrogen Retention in Crossbred Native Chicken given Salvinia

Based on Elvina (2008), there is factor that influnced energy in poultry, that is polisacaride (sellulosa and hemisellulosa) in crude fiber fraction. Polisacaride in crude fiber fraction that can be digested will increasing an energy suply for poultry. Based on Sumiati and Nurhaya (2003), hemisellulosa content of Salvinia is higher than sellulosa, hemisellulosa content of Salvinia is $11,35 \%$, while sellulosa is $8,11 \%$, and hemisellulosa have a higher digestibility $(66,67 \%)$ than sellulosa $(5,28 \%)$. Nitrogen retention that resulted in this treatment $(\mathrm{T} 1, \mathrm{~T} 2, \mathrm{~T} 3)$ is better that reported by Iskandar et al. (2001). Iskandar et al. (2001) found that nitrogen retention in 12 weeks old of crossbred native chicken that feeding with $19 \%$ protein is $1,52 \mathrm{~g}$.

Muscle protein mass also indicated similar pattern as that of other parameters described previously. Feeding Salvinia (T1, T2, T3) resulted significantly higher $(\mathrm{P}<0.05)$ muscle protein mass when compared to control (T0), however, there was no difference among T1, T2, and T3 (Figure 3). It can be clearly described that muscle protein mass was getting better because of the feeding Salvinia. Considering Salvinia contains higher protein $(32.25 \%)$ compared to other plant feedstuffs. It is very logic that the higher protein supply bring about the better metabolism for growth through the increase in body protein synthesis indicated by muscle protein mass. According to Suthama (2006) that kedu chicken reared for 12 weeks given diet with protein content of $16.25 \%$ produced muscle protein mass by $199.4 \mathrm{~g}$ with body weight gain of $16.0 \mathrm{~g} / \mathrm{bird} /$ day.

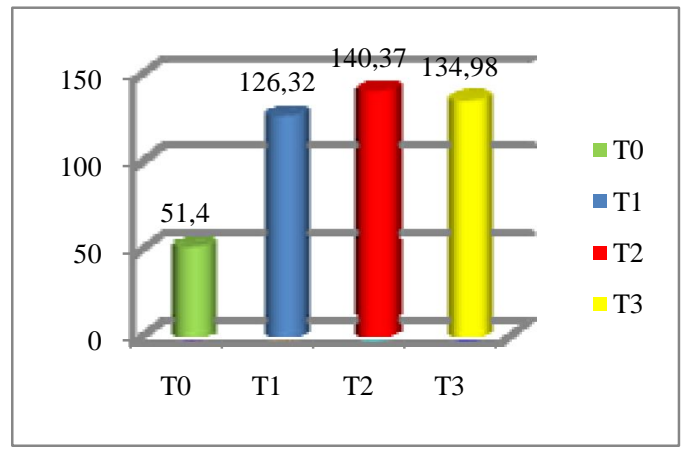

Fig. 3 Muscle Protein Mass in Crossbred Native Chicken given Salvinia

Muscle protein mass decreased following the decrease in dietary protein, on the other hand, the higher protein intake as substrate for protein synthesis bring about the increase in body protein mass (Suthama et al., 2010). Physiological process of protein metabolism involving the increase in muscle protein mass, in term of higher protein deposition measurement, and finally produced better quality growth.

All paramaters including body weight gain indicated significantly higher value $(\mathrm{P}<0.05)$ when diet containing Salvinia (T1, T2, T3) was fed compared to control (T0) as shown in Figure 4 . Body weight gain was closely related to the feed or protein consumptions and muscle protein mass. The distinctive body weight gain between the Salvinia feeding treatment and control was caused by the higher feed cosumption and level of muscle protein mass. Nutrient consumption, indicated by higher feed consumption, especially protein, functions as the substrate to built a better balance between substrate (nutrient) and hormone that takes part in growth (Suthama et al., 1998). The higher supply of dietary protein can ensure the better nutritional as well as hormonal balance and brought about lower protein degradation and higher rate of protein synthesis, producing higher muscle protein mass and finally leads to gain in body weight (Suthama et al., 2010).

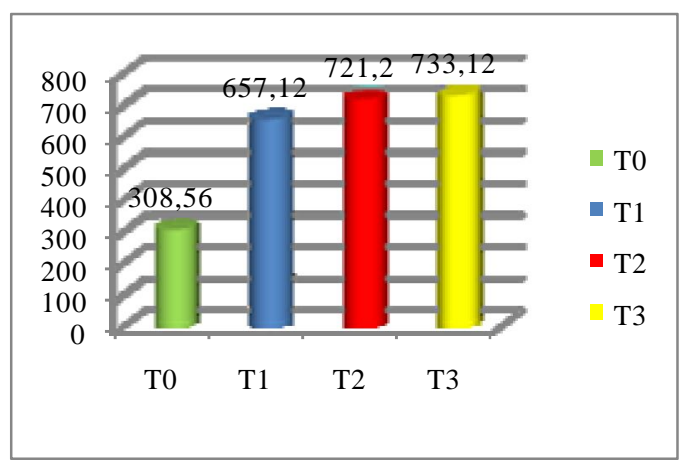

Fig. 4 Body Weight Gain in Crossbred Native Chicken given Salvinia

The body weight gain resulted from the experiment on T1, T2, and T3 was better than Kristina and Wijana (2011) finding stated that the body weight gain of native chcken that raised until 10 week with $3.000 \mathrm{kcal} / \mathrm{kg}$ energy and $20 \%$ protein is $641,93 \mathrm{~g} / \mathrm{chicken}$. Furthermore, Patrick and Schaible (1980) stated that final body weight gain is the least result of the growing process so that when the feed consumption is low, then the final weight is also low. Feed consumption on treatment with Salvinia (T1,T2, and T3) is higher than control (T0), so its resulting in better body weight gain. Rasyaf (2007) reported that bird body weight, is not only influenced by the feed intake but also by quality of diet which is given. Based on Suci et al. (2005), chicken can reach an optimal growth if nutrient contents that consumed is sufficient for its growth. Mangisah et al. (2009) state that a higher nutrient consumption that is follow with metabolic energy availability will increase a biosynthesis of meat tissue so will increasing body weght gain.

The quality of dietary treatments of T1, T2, and T3 were better than that of control because of complementery effect and balance amino acid, therefore, resulted in better body weight gain. According to Suthama (2010), protein quality relates to the balance and the need of amino acid for birds during the during growing period because the primary determinant of amino acid deposition pattern determines body weight gain. Body weight gain of the three treatments (T1, T2, and T3) due to the feeding effect of Salvinia can be 
categorized good because it was supported by the low value of feed conversion ratio (T1, T2, and T3 was 3.69, 3.56, and 3.44, respectively) as compared to control (6.43).

\section{CONCLUSION}

Feeding Salvinia up to the level of $18 \%$ can increase nitrogen retention and leads to producing better muscle protein mass and higher body weight gain.

\section{REFERENCES}

[1]. Akter, M. S.D. Chowdhury, Y. Akter, and M.A. Khatun. 2011. Effect of duckweed (Lemna minor) meal in the diet $\mathrm{f}$ laying hen and their performance. Bangladesh Res. Pub. J. 5 (3): 252-261.

[2]. Amrullah, I.K. 2004. Nutrisi Ayam Broiler. Lembaga Satu Gunungbudi, Bogor.

[3]. Anggorodi. 1994. Ilmu Makanan Ternak Umum. Cetakan ke-5. PT. Gramedia, Jakarta.

[4]. Bell, R.E. 1998. Duckweed, A Potential High Protein Feed Source for Domestic Animals and Fish. Armidale, New South Wales.

[5]. Donsbough, A.L. 2008. The Use of Serum Uric Acid As an Indicator of Amino Acid Utilization in Diets For Broilers. Thesis Master of Science, Louisiana State University, Baton Rouge.

[6]. Haloho, L. Dan M. Silalahi. 1997. Pengaruh penggunaan tepung kayambang (Salvinia molesta, D.S.) sebagai substitusi dedak halus dalam ransum ayam pedaging Arbor arces (CP-707) umur 11-54 hari. Prosiding Seminar Nasional II Ilmu Nutrisi Makanan Ternak. Fakultas Peternakan IPB dan Asosiasi Ilmu Nutrisi Makanan Ternak Indonesia. Bogor.

[7]. Iskandar, S., P. Handayani, dan D. Sudrajat. 2001. Retensi energi dan nitrogen dan laju pencernaan pada ayam silangan pelung $\mathrm{x}$ kampung pada pola pemberian ransum dengan protein berbeda. Seminar Nasional Teknologi Peternakan dan Veteriner 2001. Hal 597-605.

[8]. Kristina, D.G.A.M. dan Wijana, I.W. 2011. Pengaruh penggunaan level energi-protein ransum terhadap produksi ayam kampung. The Excellence Research Universitas Udayana 2011. Bali.

[9]. Leterme, P., Angela, M.L., Jaime, E.M., Jeimmy, S., Carlos, A.B., and Wolfgang, B.S. 2009. Nutritional value of aquatic ferns (Azolla filiculoides Lam. And Salvinia molesta Mitchell) in pigs. Anim. Feed Sci. Technol. 149: 135-148.

[10]. Mangisah I., N. Suthama and H.I. Wahyuni. 2009. Pengaruh Penambahan Starbio dalam ransum berserat kasar tinggi terhadap performa itik dalam Seminar Nasional Kebangkitan Peternakan Universitas Diponegoro, Semarang.
[11]. McFarland, D.G., L.S. Nelson, M.J. Grodowitz, R.M. Smart, and C.S. Owens. 2004. Salvinia molesta D.S. Mitchell (Giant Salvinia) in the United States : A Review of Species Ecology and Approaches to Management. US. Army Corps of Engineers. Washington.

[12]. Muryanto. 2005. Pengembangan Ayam Hibrida (Ayam Potong Lokal). Petunjuk Teknis. Balai Pengkajian Teknologi Pertanian Jawa Tengah, Ungaran.

[13]. Patrick, H. And P. J. Schaible. 1980. Poultry : Feed and Nutrition. 2nd Ed. The Avi Publishing Co. Inc. Wesport, Connecticut.

[14]. Rasyaf, M. 2007. Beternak Ayam Pedaging. Cetakan ke-27. PT. Penebar Swadaya, Jakarta.

[15]. Sibbald, I. R. 1989. Metabolizable Energy Evaluation of Poultry Diets. In Cole, D.J.A. and W. Haresign (ed). Recent Development in Poultry Nutrition. University of Nothingham School of Agriculture. Butter Worths.

[16]. Suci, D.M., E. Mursyida, T. Setianah and R. Mutia. 2005. Program pemberian makanan berdasarkan kebutuhan protein dan energi pada setiap fase pertumbuhan ayam Poncin. Med. Pet. 28 (2): 70-76.

[17]. Sumiati dan A. Sumirat. 2003. Persentase bobot saluran pencernaan dan organ dalam itik lokal (Anas platyrhyncos) jantan yang diberi berbagai taraf kayambang (Salvinia molesta) dalam ransumnya. Med. Pet. 26 (1): 11-16.

[18]. Sumiati dan A. Nurhaya. 2003. Kecernaan bahan kering, serat kasar, selulosa, dan hemiselulosa kayambang (Salvinia molesta) pada itik lokal. J. Indon. Trop. Anim. Agric. Special Edition (Oktober) 2003.

[19]. Suthama, N., S.M. Ardiningsasi, W. Murningsih, dan U. Atmomarsono. 1998. Nutrien digestibility and production performance of native chicken fed iet composed of fermented rice bran. Bull. Anim. Sci., Supllement Edition. 450-453.

[20]. Suthama, N. 2006. Kajian aspek "protein turnover" tubuh pada ayam kedu periode pertumbuhan. Med. Pet. 29 (2): 47-53.

[21]. Suthama, N. 2010. Pakan spesifik lokal dan kualitas pertumbuhan untuk produk ayam lokal organik. Pidato Pengukuhan Guru Besar Fakultas Peternakan, Universitas Diponegoro. Semarang.

[22]. Suthama, N., H.I. Wahyuni, dan I. Mangisah. 2010. Laju pertumbuhan berdasarkan degradasi protein tubuh pada ayam kedu dipelihara ex situ. Prosiding Seminar Nasional Tentang Unggas Lokal ke-IV. Semarang 7 Oktober 2010. Fakultas Peternakan Universitas Diponegoro. Hal. 138146.

[23]. Thi My Tu, D. 2012. Manipulation of The Nutritive Value of Duckwed (Lemna minor) as a Feed Resourch for Local Muscovy Ducks. Thesis in Agricultural Sciences, Animal Husbandry, Can Tho City.

[24]. Widyaratne, G.P. and M.D. Drew. 2011. Effects of protein level and digestibility on the growth and carcass characteristics of broiler chickens. Poult. Sci. 90: 595-603. 